\title{
Toward Optimal Soil Organic Carbon Sequestration and Soil Physical Properties with Effects of Conservation tillage, Organic and Synthetic Fertilizers under RWCS in an Inceptisol: A Review
}

\author{
Omkar Singh $^{1^{*}}$, R.K. Naresh ${ }^{2}$, Vivek ${ }^{2}$, Shivangi ${ }^{2}$, P.K. Singh ${ }^{3}$, \\ M. Sharath Chandra ${ }^{2}$ and Abhineet ${ }^{4}$
}

\author{
${ }^{1}$ Department of soil Science \& Agri Chemistry, ${ }^{2}$ Department of Agronomy, Sardar \\ Vallabhbhai Patel University of Agriculture \& Technology, Meerut, U. P., India \\ ${ }^{3}$ Krishi Vigyan Kendra, Sonbhadra, ${ }^{4}$ Department of Agronomy Acharya Narendra Deva \\ University Of Agriculture And Technology, Kumarganj, Ayodhya,U.P.,India
}

*Corresponding author

\begin{abstract}
A B S T R A C T
Sequestration of $\mathrm{C}$ in arable soils has been considered as a potential mechanism to mitigate the elevated levels of atmospheric greenhouse gases. We evaluated impacts of conservation agriculture on change in total soil organic $\mathrm{C}$ (SOC) and relationship between $\mathrm{C}$ addition and storage in an Inceptisol. The review study indicate the plots under zero tillage with bed planting (ZT-B) and zero tillage with flat planting (ZT-F) had nearly 28 and $26 \%$ higher total SOC stock compared with conventional tillage and bed planting (CT-B) $\left(\sim 5.5 \mathrm{Mg} \mathrm{ha}^{-1}\right)$ in the $0-5 \mathrm{~cm}$ soil layer. Plots under ZT-B and ZT-F contained higher total SOC stocks in the $0-5$ and $5-15 \mathrm{~cm}$ soil layers than CT- B plots. Although there were significant variations in total SOC stocks in the surface layers, SOC stocks were similar under all treatments in the $0-30 \mathrm{~cm}$ soil layer. The concentration of SOC at different depths in $0-60 \mathrm{~cm}$ soil profile was higher under NP+FYM follow by under NP+S, compared to under CK. The SOC storage in $0-60 \mathrm{~cm}$ in NP+FYM, $\mathrm{NP}+\mathrm{S}, \mathrm{FYM}$ and NP treatments were increased by $41.3 \%, 32.9 \%, 28.1 \%$ and $17.9 \%$, respectively, as compared to the $\mathrm{CK}$ treatment. Organic manure plus inorganic fertilizer application also increased labile soil organic carbon pools in $0-60 \mathrm{~cm}$ depth. The average concentration of particulate organic carbon (POC), dissolved organic carbon (DOC) and microbial biomass carbon (MBC) in organic manure plus inorganic fertilizer treatments $(\mathrm{NP}+\mathrm{S}$ and NP+FYM) in 0-60 cm depth were increased by $64.9-91.9 \%, 42.5-56.9 \%$, and 74.7-99.4\%, respectively, over the $\mathrm{CK}$ treatment.
\end{abstract}

\section{Introduction}

Soil organic carbon (SOC) is the largest carbon (C) pool in terrestrial ecosystems, with the storage of over $1550 \mathrm{Pg}$ globally therefore; small changes in the SOC pool may have a significant impact on climate change. The total amount of $\mathrm{C}$ stored in the top meter of soil is estimated to be $2,500 \mathrm{Pg} \mathrm{C}$ globally ( $1 \mathrm{Pg}=$ petagram $=1015 \mathrm{~g})$, including about $1,500 \mathrm{Pg}$ of $\mathrm{SOC}$, and $950 \mathrm{Pg} \mathrm{C}$ of inorganic soil C (SIC). This is about 3.3 times the 
amount of $\mathrm{C}$ in the atmospheric pool $(760 \mathrm{Pg}$ C) and about 4.5 times (560 Pg C) the amount of $\mathrm{C}$ stored in living vegetation (Lal, 2004b). The SOC pool plays an important role in the global $\mathrm{C}$ cycle and has a strong impact on agricultural sustainability, and environmental quality (Stevenson, 1994).

Agro-ecosystems, accounting for $10 \%$ of the total terrestrial area, are among the most vulnerable ecosystems to the global climate change due to their large carbon pool (Smit and Skinner, 2002). One-half to two-thirds of the original SOC pool have lost with a cumulative amount of $30-40 \mathrm{tCha}^{-1}$ in cultivated soils due to intensive farming (Lal, 2004a). Thus, adoption of a restorative management practices on agricultural soils is often required to improve the soil fertility and the environment (Lal, 2004b).

The deterioration of soil physical heath due to continuous cultivation without acceptable replenishment poses an immediate threat to soil health and environmental securities. Continuous cultivation of crops and excessive use of fertilizers is depleting the soil physical health hence; there is a need to reintroduce the age old practice of application of farmyard manure (FYM) to maintain soil fertility as well as soil health and also to supplement many essential plant nutrients for crop productivity. Balanced use of fertilizers in combination with manures is one of the best ways to prevent organic matter depletion and rapid deterioration of soil physical properties, specially soil structure (Singh et al., 2007). Addition of organic matter increases soil organic carbon content, which directly or indirectly affects physical properties of soil and processes like water-holding capacity (WHC), hydraulic conductivity and bulk density (Celik et al., 2004). While improvement in soil structural condition through the addition of $\mathrm{C}$ inputs has been profusely reported, a quantitative evaluation of soil physical properties under integrated nutrient management system. Thus, the balance and imbalanced use of nutrients through and organic manures and chemical fertilizers should be followed for the improvement of physical soil quality for sustainability. While the consequence of excessive use of mineral fertilizers adversely affected soil physico-chemical properties, which ultimately reduces the productivity as well as physical environment of soil under rice-wheat cropping system (Kakraliya et al., 2017). Organic manure along with mineral fertilizer also helps to build up soil organic matter, which increases organic carbon which improves soil aggregation and its stability, reduce soil compaction, increase porosity and water holding capacity.

Soil tillage is among the important factors affecting soil properties and crop yield. Among the crop production factors, tillage contributes up-to $20 \%$ [Khurshid et al., 2006] and affects the sustainable use of soil resources through its influence on soil properties [Lal and Stewart, 2013]. Reducing tillage positively influences several aspects of the soils whereas excessive and unnecessary tillage operations give rise to opposite phenomena that are harmful to soil. Therefore, currently there is a significant interest and emphasis on the shift from extreme tillage to conservation and no-tillage methods for the purpose of controlling erosion processes. During multiple tillage operations, SOM is redistributed within the soil profile and minor changes in it may affect the formation and stability of soil aggregates. The objectives of the review study were: (i) to assess the impact of conservation tillage based practices manure and inorganic fertilizers on rice-wheat system on soil physical properties and aggregate-associated $\mathrm{C}$ content; (ii) to know the $\mathrm{C}$-stabilization rate in different tillage practices in rice-wheat cropping systems, and (iii) to assess the effect 
of organic and inorganic fertilizers with residue retention, and tillage practices on soil organic carbon pools and soil residual fertility.

\section{Changes in SOC by tillage, $\mathrm{N}$-fertilizer and manure application}

SOC is an important index of soil quality and health and is an important component of the soil fertility of farmlands, as well as being the core of soil quality and function (Pan and Zhao, 2005). SOC content can directly affect soil fertility and crop yield, and greatly affects the formation and stability of the water-stable soil aggregate structure (Cai et al., 2009).

West and Post (2002) found the average relative increased SOC stock was $0.57 \pm 0.14$ $\mathrm{Mg} \mathrm{C} \mathrm{ha}{ }^{-1} \mathrm{yr}^{-1}$, with $75 \%$ of the studies showing increased SOC stocks. Gollany et al., (2006) found that increased SOC storage in the fine organic matter fraction with reduced tillage ranged from 0.16 to $0.18 \mathrm{Mg} \mathrm{C} \mathrm{ha}^{-1}$ at $\mathrm{N}$ fertilizer rates of 15 and $180 \mathrm{~kg} \mathrm{~N} \mathrm{ha}^{-1}$ under long-term wheat-fallow system, compared to moldboard plowed soils. Angers and Eriksen-Hamel, (2008) also found there was a small, but significant increase in total SOC stocks under no-tillage, but all of this increase was observed in the upper $10 \mathrm{~cm}$. This can be explained by residue burial to a greater depth due to tillage and shows that limited depth of soil sampling could result in over- or under-estimation of SOC stocks. Gupta Chaudhary et al., (2014) reported that conservation tillage (both RT and ZT) caused $21.2 \%, 9.5 \%, 28.4 \%, 13.6 \%, 15.3 \%, 2.9 \%$ and $24.7 \%$ higher accumulation of SOC in $>2 \mathrm{~mm}$, 2.1-1.0 mm,1.0-0.5 mm, 0.5-0.25 mm,0.25$0.1 \mathrm{~mm}, 0.1-0.05 \mathrm{~mm}$ and $<0.05 \mathrm{~mm}$ sized particles than conventional tillage $\left(T_{1}\right.$ and $\left.T_{2}\right)$ treatments. Direct seeded rice combined with zero tillage and residue retention $\left(\mathrm{T}_{6}\right)$ had the highest capability to hold the organic carbon in surface $\left(11.57 \mathrm{~g} \mathrm{~kg}^{-1}\right.$ soil aggregates) and retained least amount of SOC in sub-surface (9.05 $\mathrm{gkg}^{-1}$ soil aggregates) soil. In comparison with transplanted rice (TPR), direct seeded rice (DSR) enhanced $16.8 \%$, $7.8 \%, 17.9 \%, 12.9 \%, 14.6 \%, 7.9 \%$ and $17.5 \%$ SOC in>2mm, 2.1-1.0mm,1.0-0.5 mm,0.5$0.25 \mathrm{~mm}, \quad 0.25-0.1 \mathrm{~mm}, 0.1-0.05 \mathrm{~mm}$ and $<0.05 \mathrm{~mm}$ sized particles.

Aulakh et al., (2013) also found that in 0 - 5 $\mathrm{cm}$ layer of CT system, $\mathrm{T}_{2}, \mathrm{~T}_{3}$ and $\mathrm{T}_{4}$ treatments increased TOC content from 3.84 $\mathrm{gkg}^{-1}$ in control $\left(\mathrm{T}_{1}\right)$ to $4.19,4.33$ and 4.45 $\mathrm{gkg}^{-1}$ without CR, and to $4.40,4.83$ and 5.79 $\mathrm{gkg}^{-1}$ with $\mathrm{CR}\left(\mathrm{T}_{6}, \mathrm{~T}_{7}\right.$ and $\left.\mathrm{T}_{8}\right)$ after 2 years. The corresponding values of TOC content under CA system were $4.55 \mathrm{gkg}^{-1}$ in control to $4.73,4.79$ and $5.02 \mathrm{gkg}^{-1}$ without $\mathrm{CR}$ and to 4.95, 5.07 and $5.30 \mathrm{gkg}^{-1}$ with CR. After 4 years of these treatments, there was further improvement in TOC content from $1 \%$ to $26 \%$ in CT and none to $19 \%$ in CA treatments. Liu et al., (2013) reported that the distribution of SOC with depth was dependent on the use of various fertilizers. The highest SOC concentration was obtained for $0-20 \mathrm{~cm}$ depth and decreased with depth for all treatments. The SOC concentration in $0-20$, 20-40 and 40-60 cm depths increased significantly by farmyard manure or straw application. At the $0-20$ and $20-40 \mathrm{~cm}$ soil depths, SOC was highest in NP+FKM followed by $\mathrm{NP}+\mathrm{S}$ and FYM treatments and the least in $\mathrm{CK}$ treatment. However, the topsoil $(0-20 \mathrm{~cm})$ had the maximum levels of cumulative SOC storage in the $1 \mathrm{~m}$ soil depth for the CK, N, NP, FYM, NP+S and $\mathrm{NP}+\mathrm{FYM}$ treatments, accounting for $24 \%$, $23 \%, 27 \%, 30 \%, 31 \%$ and $31 \%$, respectively. At the $20-40 \mathrm{~cm}$ and $40-60 \mathrm{~cm}$ soil layers, the SOC stocks of the NP, FYM, NP+S and $\mathrm{NP}+\mathrm{FYM}$ treatments were significantly higher by $17 \%, 21 \%, 25 \%$ and $37 \%$ and $5.3 \%, 8.1 \%, 7.3 \%$ and $11 \%$, respectively, than that of the CK. The differences of SOC storage between different treatments were not 
significant in the $60-80 \mathrm{~cm}$ and $80-100 \mathrm{~cm}$ soil layers. SOC storages were significantly different between fertilization treatments in the $0-100 \mathrm{~cm}$ profile. Compared with the CK treatment, SOC storages of the NP+FYM, $\mathrm{NP}+\mathrm{S}, \mathrm{FYM}$ and NP treatments within the 0 $100 \mathrm{~cm}$ soil depth were increased by nearly $30,24,20$ and $12 \%$, respectively.

Zheng et al., (2018) also found that the SOC content for different treatments decreased with soil depth with significantly higher content in the topsoil than in the sub-layer. At the $0-10 \mathrm{~cm}$ depth, the mean SOC varied with treatment, with the conservation tillage (ST and NT) significantly higher than conventional tillage (CT). At $10-30 \mathrm{~cm}$, especially, the ST treatment was significantly higher. At $20-30 \mathrm{~cm}$, the mean SOC from greatest to smallest was ordered $\mathrm{ST}>\mathrm{MP}>\mathrm{CT}>\mathrm{NT}$, with $\mathrm{ST}$ significantly higher than other treatments. Xin et al., (2015) revealed that soil OC concentrations were increased with residue retention, and the increases varied with soil depth (Table 1). In the $0-10 \mathrm{~cm}$ layer, soil OC concentrations of the treatments with crop residues were $6 \%$ higher than that of the treatments without residues. Soil OC concentrations under 4TS (plowing every 4 years with residue) and NTS were 18 and $22 \%$ higher than that of $\mathrm{T}$ across the three years. In the 10-20 cm layer, soil OC concentration under TS (plowing every year with residue) was $7 \%$ higher than that of $\mathrm{T}$ across the three years, but there was no significant difference between NTS and NT.

Zhang et al., (2016) reported that increasing the rate of fertilizer application could increase SOC levels linearly by enhancing residue accumulation (Fig.1). The fertilizer N application rates are 1.5 and 2.0 times of the baseline level, the average annual SOC changes are 1.37 and 1.55 times that of the baseline level, respectively (Fig.1). In contrast, reduced $\mathrm{N}$-fertilizer and no $\mathrm{N}$ - fertilizer application would significantly reduce the SOC. The average annual SOC changes were -33 and $-330 \mathrm{~kg} \mathrm{C}^{-1} \mathrm{yr}^{-1}$ for the $0.5 \mathrm{FL}$ and NFL scenarios, respectively and the corresponding SOC changes are $142 \%$ and $522 \%$ lower than the baseline scenario. Increased mineral $\mathrm{N}$ fertilizer rate that increases $\mathrm{C}$ sequestration often has adverse effects on emissions of greenhouse gases (e.g., $\mathrm{N}_{2} \mathrm{O}$ ) (Desjardins et al., 2001).

The application of crop residues without supplemental fertilizer $\mathrm{N}$ will not generally meet crop $\mathrm{N}$ demand, and thus may lead to yield decline. However, the return of crop residues over the long term may lead to a buildup of readily mineralized organic soil $\mathrm{N}$, and potentially a reduction in $\mathrm{N}$ fertilizer requirements. Soil type, crop residue management and tillage practices and climatic conditions may also have an important impact on SOC storage in agricultural systems with a diversity of best management practices (Ogle et al., 2015; Fujisaki et al., 2018).

Ogle et al., (2015) observed that greater increases in SOC upon conversion from conventional tillage to no-till in tropical moist (23\% increase) $>$ tropical dry $(17 \%$ increase) $>$ temperate moist $(16 \%$ increase $)>$ temperate dry (10\% increase) climates. Hence, agricultural management impacts on SOC storage and dynamics can be sensitive to climatic conditions in different agro-regions which may be further driven by plant-derived $\mathrm{C}$ inputs, particularly in tropical croplands with a greater influence on SOC priming (Lenka et al., 2019). Figure 2 showed that it is evident that $\mathrm{N}$ is released from crop residues in both organic and inorganic forms; most organic $\mathrm{N}$ is not available to plants directly. While a small portion of crop residue $\mathrm{N}$ may be mineralized immediately after application, a larger portion will become immobilized in the soil microbial pool, later to be mineralized or transformed into other SOM pools as 
microbial byproducts (Kopittke et al., 2018; Sarker et al., 2018b). This mineralized N may be taken up by crop plants, recycled in the microbial biomass, or lost from the soil-plant system via leaching, erosion, or in gaseous form. A portion of the crop residue $\mathrm{N}$ may enter the complex SOM pools or organo mineral fractions (Lehmann and Kleber, 2015).

\section{SOC fractions}

Gue et al., (2016) reported that compared with CT treatments, NT treatments did not affect SOC concentration of bulk soil in the 5-20 cm soil layer, but significantly increased the SOC concentration of bulk soil in the $0-5$ $\mathrm{cm}$ soil layer. In comparison with $\mathrm{NS}$ treatments, $\mathrm{S}$ treatments had not significant effects on SOC concentration of bulk soil in the $5-20 \mathrm{~cm}$ soil layer, but significantly enhanced the SOC concentration of bulk soil in the $0-5 \mathrm{~cm}$ soil layer. In the $0-5 \mathrm{~cm}$ soil layer, NT treatments significantly increased SOC concentration by $5.8 \%, 6.8 \%$, and $7.9 \%$ of bulk soil, $>0.25 \mathrm{~mm}$ aggregate, and $<0.25$ $\mathrm{mm}$ aggregate, respectively, compared with CT treatments. NT treatments significantly increased MBC of bulk soil, >0.25 $\mathrm{mm}$ and $<0.25 \mathrm{~mm}$ aggregates by11.2\%, $11.5 \%$ and 20.0\%, respectively, compared with CT treatments. DOC concentrations of bulk soil, $>0.25 \mathrm{~mm}$ aggregate, and $<0.25 \mathrm{~mm}$ aggregate under NT treatments were $15.5 \%$, $29.5 \%$, and $14.1 \%$ higher than those under CT treatments, respectively. In comparison with NS treatments, $S$ treatments significantly increased SOC concentrations of bulk soil by $12.8 \%,>0.25 \mathrm{~mm}$ aggregate by $11.3 \%$, and $<0.25 \mathrm{~mm}$ aggregate by $14.1 \%$. In addition, MBC of bulk soil, $>0.25 \mathrm{~mm}$ aggregate, and $<0.25 \mathrm{~mm}$ aggregate under $\mathrm{S}$ treatments were $29.8 \%, 30.2 \%$, and $24.1 \%$ higher than those of NS treatments, respectively. S treatments exhibited $25.0 \%, 37.5 \%$, and $23.2 \%$ higher DOC concentrations of bulk soil, $>0.25 \mathrm{~mm}$ aggregate, and $<0.25 \mathrm{~mm}$ aggregate compared with NS treatments, respectively. In the 0-5 $\mathrm{cm}$ soil layer, there were significant interactions of tillage and straw returning on SOC concentration of $>0.25 \mathrm{~mm}$ and $<0.25$ $\mathrm{mm}$ aggregates, MBC of bulk soil and $<0.25$ $\mathrm{mm}$ aggregate, and DOC concentration of $>0.25 \mathrm{~mm}$ aggregate.

Anantha et al., (2018) also found that the magnitude of carbon pools extracted under a gradient of oxidizing conditions was as follows: $\mathrm{C}_{\mathrm{VL}}>\mathrm{C}_{\mathrm{LL}}>\mathrm{C}_{\mathrm{NL}}>\mathrm{C}_{\mathrm{L}}$ constituting about 41.4, 20.6, and 19.3 and $18.7 \%$, respectively, of the TOC (Table 2). However, the contribution of VL, L and LL pools to SOC was 51.2, 23.1 and $25.5 \%$, respectively. While active pool $\left(\mathrm{C}_{\mathrm{VL}}+\mathrm{C}_{\mathrm{L}}\right)$ constituted about $60.1 \%$, passive pool $\left(\mathrm{C}_{\mathrm{LL}}+\mathrm{C}_{\mathrm{NL}}\right)$ represented $39.9 \%$ of the TOC. Among the treatments, $100 \%$ NPK+FYM (44.4\%) maintained a proportionately higher amount of soil $\mathrm{C}$ in passive pools. With an increase in the dose of fertilization, on average, $\mathrm{C}$ allocation into passive pool was increased (33.0, 35.3, 40.7\% and $39.3 \%$ of TOC under control, 50\% NPK, $100 \%$ NPK and $150 \%$ NPK treatments, respectively).

\section{Carbon restoration in soil profile}

The stability of soil aggregates determines the ability of the aggregates to resist exogenic action and to remain stable when exposed to changes in the external environment. In addition, aggregates are known to closely correlate with the soil erodibility and appear to play an important role in maintaining the stability of soil structure. Almost $90 \%$ of SOC exists in the form of aggregates in the topsoil. Therefore, study of intra-aggregate $\mathrm{C}$ is of great significance to the influence of human disturbance on SOC (Zheng et al., 2013.) Naresh et al., (2015) reported that the highest SOC concentration of $5.8 \mathrm{~g} \mathrm{~kg}^{-1}$ in the surface layer $(0-15 \mathrm{~cm})$ was observed in $\mathrm{F}_{4}$ followed 
by that in $\mathrm{F}_{6}\left(5.4 \mathrm{~g} \mathrm{~kg}^{-1}\right)$ treatment. All plots treated with organic amendments contained higher SOC concentration in the surface and sub-soil compared with those not receiving any organics. The SOC concentration also improved with the application of $\mathrm{F}_{3}$ (5.1 $\mathrm{g} \mathrm{kg}^{-1}$ ) and $\mathrm{F}_{5}\left(4.9 \mathrm{~g} \mathrm{~kg}^{-1}\right)$. In contrast, the SOC concentration increased with the application of organic materials even in the sub-soil. The mean pro-file SOC concentration increased from $2.2 \mathrm{~g} \mathrm{~kg}^{-1}$ in $\mathrm{F}_{1}$ to $4.4 \mathrm{~g} \mathrm{~kg}^{-1}$ in $\mathrm{F}_{4}$. However, no increase in SOC concentration was observed in treatment $F_{2}$ (Table 3 ). It is widely recognized that the use of organic manures and compost enhances the SOC concentration more than does the use of the same amount of nutrients applied as chemical fertilizers.

Awanish (2016) revealed that the greater variations among carbon fractions were observed at surface layer $(0-5 \mathrm{~cm}) . \mathrm{F}_{1}=$ very labile, $\mathrm{F}_{2}=$ labile, $\mathrm{F}_{3}=$ less labile and, $\mathrm{F}_{4}=$ nonlabile. At this depth, $\mathrm{C}$ fraction in vertisols varied in this order: $F_{4}>F_{1}>F_{2}=F_{3}$. Below 5 $\mathrm{cm}$, the carbon fraction was in the order: $\mathrm{F}_{4}>$ $F_{1}>F_{3}>F_{2}$. For $15-30 \mathrm{~cm}$ depth it was in the order $F_{4}>F_{1}>F_{2}>F_{3}$. At lower depth, almost similar trend was followed as that of 30-45 $\mathrm{cm}$. Regardless of tillage system, contribution of different fractions of carbon (C) to the TOC varied from, 33 to $41 \%$; 9.30 to $30.11 \%$; 8.11 to $26 \%$; 30.6 to $45.20 \%$ for very labile, labile, less labile and non-labile fractions, respectively at $0-5 \mathrm{~cm}$ depth. For subsurface layer $(5-15 \mathrm{~cm})$, contribution of different fractions to the TOC varied from 27.8 to $40 \%$; 7.80 to $12.40 \% ; 11.11$ to $19.0 \% 38.0$ to $50.0 \%$ for very labile, labile, less labile and non-labile fraction, respectively. In general, $\mathrm{C}$ contents decreased with increasing depth, mainly for very labile faction (F1) which was contributing around $40 \%$ or more in surface and surface layers $(0-5$ and $5-15 \mathrm{~cm})$ as compared to deeper layers (15-30 and 30-45 $\mathrm{cm})$. Moreover, less labile and non-labile fractions contribute more than $50 \%$ of TOC, indicating more recalcitrant form of carbon in the soil.

Das et al., (2016) revealed that among the OOC fractions, $\mathrm{C}_{\mathrm{VL}}$ in the 0-7.5, 7.5-15 and $15-30 \mathrm{~cm}$ soil depths was in the range 1.02$2.51, \quad 0.72-2.09$ and $0.58-1.15 \mathrm{~g} \mathrm{~kg} \mathrm{~kg}^{-1}$ respectively, with corresponding mean values of $1.71,1.43$ and $0.90 \mathrm{~g} \mathrm{~kg}^{-1}$. At the $0-7.5 \mathrm{~cm}$ soil depth, the lowest $\mathrm{C}_{\mathrm{VL}}$ was seen in the unfertilized control treatment $\left(1.02 \mathrm{~g} \mathrm{~kg}^{-1}\right)$ and CVL increased significantly under IPNS treatments, with particularly high values $(2.51$ $\mathrm{g} \mathrm{kg}^{-1}$ ) under the NPK + GR + FYM treatment. This treatment also had the highest $\mathrm{C}_{\mathrm{VL}}$ values at the 7.5-15 and 15-30 cm depths (2.09 and $1.15 \mathrm{~g} \mathrm{~kg}^{-1}$ respectively). At 7.5-15 and 15-30 $\mathrm{cm}$ soil depths, the lowest $\mathrm{C}_{\mathrm{VL}}$ values were observed under the NPKZn treatment ( 0.72 and $0.58 \mathrm{~g} \mathrm{~kg}^{-1}$ respectively) rather than in the unfertilized control. Compared with uncultivated soil, the CVL content was lower under control or NPKZn treatments, but was invariably greater under treatments using combinations of FYM, GR or SPM with NPK fertilizers. The percentage change in CVL over uncultivated soil varied from-38\% to $109 \%$ at different depths. However, the $\mathrm{C}_{\mathrm{NL}}$ content at the 0 $7.5,7.5-15$ and $15-30 \mathrm{~cm}$ soil depths varied, with values in the range $7.23-10.07,6.73-$ 8.63 and $4.30-6.40 \mathrm{~g} \mathrm{~kg}^{-1}$ respectively, and corresponding mean values of $7.99,7.73$ and $5.39 \mathrm{~g} \mathrm{~kg}^{-1}$. Averaged across treatments, the $\mathrm{C}_{\mathrm{NL}}$ content at the $0-7.5$ and $7.5-15 \mathrm{~cm}$ depths was similar, but decreased significantly at the $15-30 \mathrm{~cm}$ soil depth. Averaged across soil depths, CNL content under the NPK + CR and NPK + GR + FYM treatments (7.99 and $7.63 \mathrm{~g} \mathrm{~kg}^{-1}$ respectively) were significantly higher than in the other treatment groups. Compared with uncultivated soil, the change in $\mathrm{C}_{\mathrm{NL}}$ under different nutrient supply options was inconsistent, although $\mathrm{C}_{\mathrm{NL}}$ content increased 
under the NPK+CR treatment by $25-33 \%$ at the $0-7.5$ and 7.5-15 depths. Considering overall mean values across soil depths and nutrient supply options, the abundance of these four OOC fractions was in the order $\mathrm{C}_{\mathrm{NL}}\left(7.04 \mathrm{~g} \mathrm{~kg}^{-1}\right)>\mathrm{C}_{\mathrm{L}}\left(2.02 \mathrm{~g} \mathrm{~kg}^{-1}\right)>\mathrm{C}_{\mathrm{VL}}$ $\left(1.35 \mathrm{~g} \mathrm{~kg}^{-1}\right)>\mathrm{C}_{\mathrm{LL}}\left(0.75 \mathrm{~g} \mathrm{~kg}^{-1}\right)$.

Ghosh et al., (2018) observed that SOC accumulation rates in plots under NPK+FYM and NPK in the $0-90 \mathrm{~cm}$ soil profile were $\sim 745$ and $529 \mathrm{~kg} \mathrm{ha}^{-1} \mathrm{yr}^{-1}$. However, C sequestration rates in the $0-90 \mathrm{~cm}$ soil profile for NPK and NPK+FYM treatments were only $\sim 167$ (31\% of the accumulated SOC) and $224 \mathrm{~kg} \mathrm{ha}^{-1} \mathrm{yr}^{-1}$, respectively.

Interestingly, NPK, $150 \% \quad$ NPK and $\mathrm{NPK}+\mathrm{FYM}$ treated plots had similar recalcitrant $\mathrm{C}$ contents in the said soil profile, but had significantly different $\mathrm{C}$ accumulation rates.

Nearly $54 \%$ of the accumulated SOC and $34 \%$ of the sequestered SOC under $\mathrm{NPK}+\mathrm{FYM}$ plots were observed within deep soils (30-90 cm soil layer), implying role of INM on $\mathrm{C}$ sequestration in deep soils. Zheng et al., (2018) observed that the SOC storage in macro-aggregates under different treatments significantly decreased with soil depth. However, no significant variation was observed in the micro-aggregate-associated C storage with depth. SOC storage increased with aggregate size from $1-2$ to $>2 \mathrm{~mm}$ and decreased with a decrease in aggregate size. The SOC storage in macro-aggregates of all sizes from $0-30 \mathrm{~cm}$ depth was higher in the ST treatment than in other treatments. From 30$60 \mathrm{~cm}$, trends were less clear. SOC storage in micro-aggregates showed the opposite trend, with significantly higher levels in the CT treatment from $0-30 \mathrm{~cm}$, and no significant differences between treatments below this depth.
Soil physical properties affected by tillage, organic and synthetic fertilizers

Zhang et al., (2007) reported no-tillage practices improve soil aggregation and aggregate stability. The increase in aggregate stability contributes to increased soil water infiltration and resistance to wind and water erosion. Macro-aggregate stability (> $250 \mu \mathrm{m}$ diameter) is particularly sensitive to changes in management practices (Zibilske and Bradford, 2007). The loss of macro-aggregate occluded organic matter is a primary source of $\mathrm{C}$ lost due to changes in management practices (Jiao et al., 2006). Continuous cropping with reduced fallow frequency and no-tillage has a positive effect on macroaggregate formation and stabilization (Mikha et al., 2010). Liu et al., (2013) also found that an application of manure and fertilizer significantly affected soil bulk density (BD) to a depth of $40 \mathrm{~cm}$. The addition of FYM or straw (FYM, NP+FYM and NP+S) treatments decreased soil bulk density significantly in comparison to that in control plots in all the layers. However, the decrease was more in upper soil layers $(0-20$ and $20-40 \mathrm{~cm})$ than in the lower layers (40-60, 60-80 and 80-100 $\mathrm{cm})$. Similar was the case with NP treatment, where BD was lower than that in CT treatment at 0-20 and 20-40 cm depths.

Pant and Shri Ram (2018) also found that in $0-60 \mathrm{~cm}$ soil layers, the bulk density was significantly lower in $100 \%$ NPK + FYM over other treatments. The balanced application of NPK decreased the bulk density in all the soil depths. Irrespective of soil depths, the control plot invariably showed higher bulk density. The soil receiving $100 \%$ NPK fertilizers with FYM recorded significantly higher hydraulic conductivity, water holding capacity and mean weight diameter in soils of all four depths, respectively as compared to control and all other fertilizer treatments (Fig. 3a, 3b; and 4a). 
Whalen et al., (2003) revealed that the proportion of WSA $>4 \mathrm{~mm}$ was greater in soils receiving compost than soils that did not receive compost and there were fewer WSA $<0.25 \mathrm{~mm}$ in compost-amended than unamended soils (Fig. 4b). In addition, there were fewer WSA between 0.25 and $1 \mathrm{~mm}$ in compost amended than un-amended soils. The MWD of aggregates increased linearly with increasing rates of compost application. Aggregation is influenced by the chemical composition of organic residues added to soils. Organic residues that decompose quickly may produce a rapid but temporary increase in aggregation, whereas organic residues that decompose slowly may produce a smaller but long lasting improvement in aggregation (Sun et al., 1995).

Bhattacharyya et al., (2008) observed that an increments in hydraulic conductivity up to 45cm depth after 8 years of farmyard manure application in a silty clay loam soil of India. Saturated hydraulic conductivity (Ksat) values in all the studied soil depths were significantly greater under ZT than those under CT (range from 300 to $344 \mathrm{~mm} /$ day) and the unsaturated conductivity $\{\mathrm{k}(\mathrm{h})\}$ values at $0-75 \mathrm{~mm}$ soil depth under ZT were significantly higher than those computed under CT at all the suction levels, except at $\% 10, \% 100$ and \% $400 \mathrm{kPa}$ suction. Abid and Lal (2009) observed that significantly higher infiltration in no till ( $\mathrm{I}=71.4 \mathrm{~cm})$ than conventional till $(\mathrm{I}=48.9 \mathrm{~cm})$ on silt loam soil. Tillage and residue management also influenced cumulative and steady-state infiltration. Retention of the straw on the surface also significantly influenced the cumulative infiltration and steady state infiltration (104 mm, $73 \mathrm{~mm} \mathrm{~h}^{-1}$ ) as compared to residue removal $\left(84 \mathrm{~mm}, 54 \mathrm{~mm} \mathrm{~h}^{-1}\right)$.

Singh et al., (2014) reported that saturated hydraulic conductivity (Ks) values for various depths of soils were largely higher under ZT than that of CT; however, differences were significant to a depth of $0.10 \mathrm{~m}$. The magnitude of increase in Ks of surface $0.05 \mathrm{~m}$ depth was highest in loam $(51 \%)$ followed by sandy loam (40\%) and clay loam (38\%) soil. Since $K s$ is a function of the size and continuity of pores, therefore, higher accumulation of soil organic carbon and less soil disturbance in ZT might have promoted the formation of macro pores responsible for higher water transmission as compared to CT practices. Naresh et al., (2015) also found that the infiltration rate was consistently highest with an overall average of $84.7 \mathrm{~mm} \mathrm{~h}^{-1}$ (raised bed), lowest at $50.3 \mathrm{~mm} \mathrm{~h}^{-1}$ in conventional tillage (puddling), and intermediate 55.7; 62.2 $\mathrm{mm} \mathrm{ha} \mathrm{h}^{-1}$ in rotary tillage and zero tillage. Infiltration after permanent wide raised beds and zero till flat beds increased with time, indicating improvement in soil structure, as also supported by soil aggregation.

Naresh et al., (2016) reported that mean soil bulk density in the 0 - to $20-\mathrm{cm}$ soil layer of the FIRB with residue retention and $\mathrm{ZT}$ with residue retention plots was 12.4 and6.8\% lower, respectively, than the CT plots. In addition, the FIRB treatment had significantly lower soil bulk density in the 0 - to 10 - and 10 - to $20-\mathrm{cm}$ soil layers than CT by 14.3 and $12.8 \%$, respectively. The changes in bulk density were mainly confined to top $10-15 \mathrm{~cm}$ layer.

Xin et al., (2015) observed that the proportion of macro-aggregates was larger than that of the other aggregate fractions (Fig. 4a). Macroaggregates accounted for 38-64, 48-66, and $54-71 \%$ of the total soil mass in the $0-5,5-$ 10 , and 10-20 $\mathrm{cm}$ soil depths, respectively. The corresponding proportions of the silt +clay fraction were $3-7,2-6$, and $1-5 \%$, respectively. Proportions of macro-aggregates were increased with reduction of soil tillage frequency (Fig. 5a). For the $0-5 \mathrm{~cm}$ soil depth, treatments NT and 4T had significantly 
higher mass proportions of macro-aggregates (36 and 23\%, respectively) than that of treatment $\mathrm{T}$. In the $5-10 \mathrm{~cm}$ layer, the proportions of macro-aggregates of NT and 4T were 24 and $15 \%$ higher than that in $\mathrm{T}$, respectively. In the $10-20 \mathrm{~cm}$ depth, the proportions of macro-aggregates of NT and 4T were 21 and $14 \%$ higher than that of $\mathrm{T}$. However, the MWD (mean weight diameter) and GMD (geometric mean diameter) values were significantly increased with the reduced frequency of plowing at all depths (Fig. 5b). In the 0-5 cm layer, compared with $\mathrm{T}$, values of MWD under 4T and NT were increased by 41 and $68 \%$, respectively. Values of MWD under NT in the 5-10 and 10-20 cm depths were increased by 41 and $28 \%$ as compared to that under $\mathrm{T}$. The highest GMD value appeared in NTS, while the lowest appeared in $\mathrm{T}$ across all soil depths. Additionally, residue retention had pronounced positive effects on MWD and GMD. The average MWD values among crop residue treatments were 30,15 and $14 \%$ higher than the corresponding treatments without crop residues in the $0-5,5-10$, and $10-20 \mathrm{~cm}$ depths, respectively.

Bandyopadhyay et al., (2010) also found that straw incorporation helps in the formation and stability of aggregates through increase in microbial cell and microbial excretions and its decomposition products released during the death of microorganisms. Soils receiving rice straw along with NPK had more water stable macro-aggregates $(74.2 \%)$, higher aggregate stability $(73.24 \%)$, mean weight diameter $(0.89 \mathrm{~mm})$ and geometric mean diameter $(0.89 \mathrm{~mm})$ than the control treatment (Table $4)$. There is a meager variation in structural indices due to paddy rice straw incorporation but influences the soil hydro-physical environment in rice-rice system in clayey soil. It increased the hydraulic conductivity, porosity and water retention capacity.

Singh et al., (2014) reported that a significant increase in bulk density was observed in surface $0.05 \mathrm{~m}$ in sandy loam and $0.10 \mathrm{~m}$ in both loam and clay loam soils (Fig.6a). Saturated hydraulic conductivity increased significantly only to a depth of $0.10 \mathrm{~m}$ but with varying magnitudes. Increase in magnitude in surface $0.05 \mathrm{~m}$ layer was highest in loam $(51 \%)$ followed by sandy loam $(40 \%)$ and clay loam (38\%) soil (Fig. 6b). Although ZT increased water retention and aeration porosity but increase in field water capacity was significant to a deeper depth $(0.15 \mathrm{~m})$ in clay loam soil (Fig.6b).

Table.1 Soil OC concentration in the 0-10 and 10-20 cm depths in 2011-2013

\begin{tabular}{|c|c|c|c|c|c|c|}
\hline \multirow{2}{*}{ Treatment } & \multicolumn{2}{|c|}{ Soil OC in $2011\left(\mathrm{~g} \mathrm{Kg}^{-1}\right)$} & \multicolumn{2}{|c|}{ Soil OC in $2012\left(\mathrm{~g} \mathrm{Kg}^{-1}\right)$} & \multicolumn{2}{|c|}{ Soil OC in $2013\left(\mathrm{~g} \mathrm{Kg}^{-1}\right)$} \\
\hline & $0-10 \mathrm{~cm}$ & $10-20 \mathrm{~cm}$ & $0-10 \mathrm{~cm}$ & $10-20 \mathrm{~cm}$ & $0-10 \mathrm{~cm}$ & $10-20 \mathrm{~cm}$ \\
\hline TS & $6.89 \pm 0.55 d$ & $6.82 \pm 0.18 \mathrm{a}$ & $7.62 \pm 0.35 b c$ & $6.41 \pm 0.18 b$ & $7.73+0.16 b$ & $6.52 \pm 0.18 b$ \\
\hline 2TS & $7.35 \pm 0.76 \mathrm{~cd}$ & $6.68 \pm 0.45$ & $7.47 \pm 0.23 b c$ & $6.55 \pm 0.37$ & $7.57 \pm 0.17 b c$ & $6.67 \pm 0.28 \mathrm{ab}$ \\
\hline 4TS & $8.00 \pm 0.44 b$ & $6.75 \pm 0.32 a$ & $8.21 \pm 0.30 \mathrm{a}$ & $6.67 \pm 0.35 \mathrm{ab}$ & $8.31 \pm 0.23 a$ & $6.78 \pm 0.35 \mathrm{ab}$ \\
\hline NTS & $8.16 \pm 0.32 a$ & $5.86 \pm 0.84 c$ & $8.59 \pm 0.48 a$ & $6.92 \pm 0.34 \mathrm{a}$ & $8.69 \pm 0.22 \mathrm{a}$ & $7.03 \pm 0.25 a$ \\
\hline $\mathbf{T}$ & $7.10 \pm 0.62 d$ & $6.26 \pm 0.39 b$ & $6.81 \pm 0.41 d$ & $6.08+0.51 \mathrm{c}$ & $6.91 \pm 0.22 \mathrm{~d}$ & $6.19 \pm 0.24 c$ \\
\hline $2 \mathrm{~T}$ & $6.61 \pm 0.62 d$ & $6.35 \pm 0.66 \mathrm{ab}$ & $7.20+0.41 \mathrm{~d}$ & $6.51 \pm 0.62 b$ & $7.30+0.24 \mathrm{c}$ & $6.62 \pm 0.21 \mathrm{ab}$ \\
\hline $4 \mathrm{~T}$ & $7.87 \pm 0.72 b c$ & $6.95 \pm 0.96 a$ & $7.82 \pm 0.25 b$ & $6.34 \pm 0.37 b c$ & $7.92 \pm 0.27 b$ & $6.46 \pm 0.20 b c$ \\
\hline NT & $7.53 \pm 0.93 c$ & $5.88 \pm 0.69 c$ & $8.30 \pm 0.36 a$ & $6.57 \pm 0.69 b$ & $8.40 \pm 0.22 \mathrm{a}$ & $6.68 \pm 0.16 a b$ \\
\hline
\end{tabular}


Table.2 Oxidisable organic carbon fractions (very labile, labile less labile and non-labile) in soils $\left(\mathrm{g} \mathrm{kg}^{-1}\right)$ at different layers $(\mathrm{cm})$

\begin{tabular}{|c|c|c|c|c|c|c|c|c|}
\hline \multirow[t]{2}{*}{ Treatment } & \multicolumn{4}{|c|}{ Very labile $\mathbf{C}$} & \multicolumn{4}{|c|}{ Labile C } \\
\hline & $0-15$ & $15-30$ & $30-45$ & Total & $0-15$ & $15-30$ & $30-45$ & Total \\
\hline Control & $3.6 \pm 0.5^{\mathrm{c}}$ & $1.4 \pm 0.3^{b}$ & $1.3 \pm 0.2^{\mathrm{a}}$ & $6.3 \pm 0.4^{b}$ & $2.4 \pm 0.3^{\mathrm{a}}$ & $1.0 \pm 0.2^{\mathrm{a}}$ & $0.8 \pm 0.4^{\mathrm{a}}$ & $4.2 \pm 0.6^{\mathrm{a}}$ \\
\hline $50 \%$ NPK & $4.6 \pm 0.3^{b c}$ & $2.1 \pm 0.7^{\mathrm{ab}}$ & $1.5 \pm 0.1^{\mathrm{a}}$ & $8.1 \pm 0.9^{a}$ & $1.7 \pm 0.4^{\mathrm{ab}}$ & $0.9 \pm 0.5^{\mathrm{a}}$ & $0.7 \pm 0.2^{\mathrm{a}}$ & $3.3 \pm 0.7^{\mathrm{a}}$ \\
\hline $100 \%$ NPK & $4.4 \pm 0.3^{\mathrm{bc}}$ & $2.3 \pm 0.2^{\mathrm{a}}$ & $1.4 \pm 0.5^{\mathrm{a}}$ & $8.0 \pm 0.7^{\mathrm{a}}$ & $1.8 \pm 0.4^{\mathrm{ab}}$ & $0.8 \pm 0.5^{\mathrm{a}}$ & $0.6 \pm 0.3^{\mathrm{a}}$ & $3.2 \pm 0.8^{\mathrm{a}}$ \\
\hline $150 \%$ NPK & $5.0 \pm 0.2^{\mathrm{ab}}$ & $2.6 \pm 0.2^{\mathrm{a}}$ & $1.5 \pm 0.1^{\mathrm{a}}$ & $9.0 \pm 0.3^{\mathrm{a}}$ & $1.2 \pm 0.3^{b}$ & $0.7 \pm 0.2^{\mathrm{a}}$ & $0.9 \pm 0.2^{\mathrm{a}}$ & $2.8 \pm 0.4^{\mathrm{a}}$ \\
\hline $\begin{array}{c}100 \% \text { NPK+ } \\
\text { FYM }\end{array}$ & $4.8 \pm 0.2^{\mathrm{ab}}$ & $2.0 \pm 0.2^{\mathrm{ab}}$ & $1.3 \pm 0.3^{\mathrm{a}}$ & $8.1 \pm 0.2^{\mathrm{a}}$ & $1.9 \pm 0.3^{\mathrm{ab}}$ & $0.7 \pm 0.2^{\mathrm{a}}$ & $0.7 \pm 0.2^{\mathrm{a}}$ & $3.4 \pm 0.2^{\mathrm{a}}$ \\
\hline FYM & $5.9 \pm 1.3^{\mathrm{a}}$ & $2.2 \pm 0.2^{\mathrm{a}}$ & $1.4 \pm 0.3^{\mathrm{a}}$ & $9.5 \pm 1.6^{\mathrm{a}}$ & $2.5 \pm 0.9^{\mathrm{a}}$ & $0.7 \pm 0.3^{\mathrm{a}}$ & $0.7 \pm 0.3^{\mathrm{a}}$ & $3.9 \pm 0.9^{\mathrm{a}}$ \\
\hline \multirow[t]{2}{*}{ Fallow } & $4.2 \pm 0.7^{b c}$ & $1.5 \pm 0.5^{b}$ & $0.7 \pm 0.3^{b}$ & $6.3 \pm 0.8^{b}$ & $2.2 \pm 1.0^{\mathrm{ab}}$ & $0.7 \pm 0.3^{\mathrm{a}}$ & $1.0 \pm 0.4^{\mathrm{a}}$ & $4.1 \pm 1.1^{\mathrm{a}}$ \\
\hline & \multicolumn{4}{|c|}{ Less labile C } & \multicolumn{4}{|c|}{ Non labile $\mathbf{C}$} \\
\hline Control & $1.5 \pm 0.3^{c}$ & $0.6 \pm 0.4^{c}$ & $0.4 \pm 0.0^{c}$ & $2.6 \pm 0.7^{b}$ & $1.2 \pm 0.5^{b}$ & $1.2 \pm 0.3^{\mathrm{a}}$ & $0.2 \pm 0.2^{b}$ & $2.6 \pm 0.5^{b}$ \\
\hline $50 \%$ NPK & $1.8 \pm 0.1^{\mathrm{c}}$ & $0.4 \pm 0.1^{c}$ & $0.5 \pm 0.2^{c}$ & $2.7 \pm 0.1^{\mathrm{ab}}$ & $1.2 \pm 0.9^{b}$ & $1.7 \pm 0.8^{a}$ & $0.7 \pm 0.4^{\mathrm{ab}}$ & $3.5 \pm 1.8^{\mathrm{ab}}$ \\
\hline $100 \%$ NPK & $2.5 \pm 0.3^{\mathrm{ab}}$ & $0.8 \pm 0.1^{b c}$ & $1.1 \pm 0.2^{\mathrm{ab}}$ & $4.4 \pm 0.1^{b}$ & $1.3 \pm 0.6^{b}$ & $1.5 \pm 0.6^{\mathrm{a}}$ & $0.5 \pm 0.2^{\mathrm{ab}}$ & $3.3 \pm 1.0^{\mathrm{ab}}$ \\
\hline $150 \%$ NPK & $2.6 \pm 0.2^{a}$ & $0.9 \pm 0.1^{b c}$ & $0.4 \pm 0.2^{c}$ & $3.9 \pm 0.1^{b}$ & $1.4 \pm 0 .^{b}$ & $1.5 \pm 0.2^{\mathrm{a}}$ & $0.8 \pm 0.1^{\mathrm{a}}$ & $3.7 \pm 0.3^{\mathrm{ab}}$ \\
\hline $\begin{array}{c}100 \% \text { NPK+ } \\
\text { FYM }\end{array}$ & $2.7 \pm 0.6^{\mathrm{a}}$ & $1.5 \pm 0.6^{\mathrm{a}}$ & $1.4 \pm 0.1^{\mathrm{a}}$ & $5.6 \pm 0.7^{\mathrm{a}}$ & $2.0 \pm 0.8^{b}$ & $1.3 \pm 0.1^{\mathrm{a}}$ & $0.3 \pm 0.3^{\mathrm{ab}}$ & $3.5 \pm 0.7^{\mathrm{ab}}$ \\
\hline FYM & $1.9 \pm 0.7^{b c}$ & $1.7 \pm 0.2^{\mathrm{a}}$ & $1.0 \pm 0.2^{b}$ & $4.5 \pm 0.7^{\mathrm{ab}}$ & $3.7 \pm 1.3^{\mathrm{a}}$ & $1.0 \pm 0.2^{\mathrm{a}}$ & $0.5 \pm 0.5^{\mathrm{ab}}$ & $5.1 \pm 1.9^{a}$ \\
\hline Fallow & $1.5 \pm 0.3^{\mathrm{c}}$ & $1.3 \pm 0.7^{\mathrm{ab}}$ & $0.9 \pm 0.4^{b}$ & $3.8 \pm 1.2^{\mathrm{bc}}$ & $2.1 \pm 0.2^{b}$ & $1.4 \pm 0.7^{\mathrm{a}}$ & $0.4 \pm 0.2^{\mathrm{ab}}$ & $3.9 \pm 0.9^{\mathrm{ab}}$ \\
\hline
\end{tabular}

Table.3 Changes in soil organic carbon (SOC) $\left(\mathrm{g} \mathrm{kg}^{-1}\right)$ concentration in soil after $12 \mathrm{yr}$ of tillage crop establishment and fertilization

\begin{tabular}{|c|c|c|c|c|c|c|c|c|c|}
\hline $\begin{array}{c}\text { Soil } \\
\text { Depth } \\
(\mathbf{c m})\end{array}$ & $\begin{array}{l}\text { Initial } \\
\text { (2001) }\end{array}$ & $\begin{array}{c}\mathbf{F}_{1} \\
\text { Control }\end{array}$ & $\begin{array}{c}\mathbf{F}_{2}-\mathbf{5 0 \%} \\
\text { RDF }\end{array}$ & $\begin{array}{c}F_{3-100 \%} \\
\text { RDF }\end{array}$ & $\begin{array}{r}F_{4}-1( \\
\text { Org } \\
(F Y\end{array}$ & $\begin{array}{c}\mathbf{F}_{5}-50 \% \\
\text { RDF + } \\
\mathbf{5 0 \%} \\
\text { (foliar) }\end{array}$ & \begin{tabular}{|c|} 
F $^{-}$ \\
50\% Organic \\
(FYM)+ \\
50\% RDF
\end{tabular} & $\begin{array}{l}\mathrm{F}_{7}-\mathrm{Fa} \\
\mathrm{c} \text { pra }\end{array}$ & $\mathbf{M}$ \\
\hline $\mathbf{0}$ & & & 0.0 & & & $4.9 \pm 0 . .^{23 \mathrm{C}}$ & $5.4 \pm 0.26^{\mathrm{Ba}}$ & & \\
\hline 15 & & & & & & $4.1 \pm$ & $5.2 \pm$ & & \\
\hline 31 & & & & & 5.1 & J. & 4.5 & & \\
\hline & & & & 2.8 & 3.4 & 2. & $2.7 \pm$ & & $2.3+$ \\
\hline & & & & & & & $1.9 \pm$ & & (3) \\
\hline Mean & .18 & $2+0$ & $2.5+0.1$ & $3.5+0.18^{\mathrm{Cb}}$ & $4.4+c$ & $3.2+0.17$ & $3.9+0.19^{\mathrm{Bb}}$ & 2.8 & \\
\hline
\end{tabular}

**Different letters within columns are significantly different at $\mathrm{P}=0.05$ according to Duncan Multiple Test (DMRT) for separation of means. 
Fig.1 Annual SOC change from 2001 to 2019 under different management practices

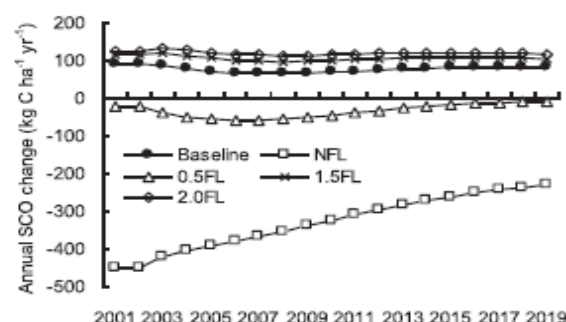
Year

(a)

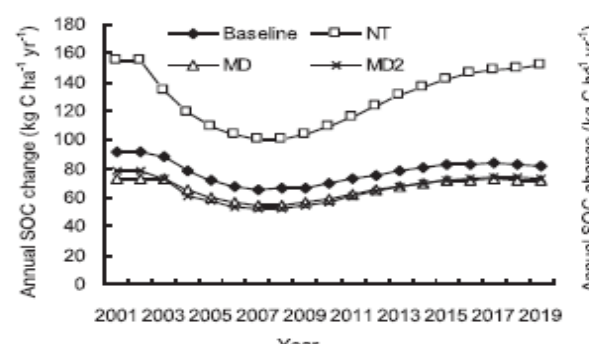

(c)

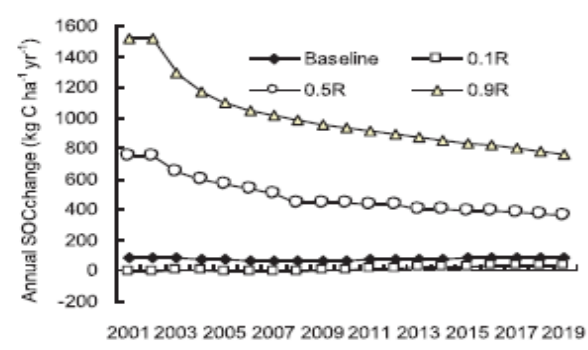

Year

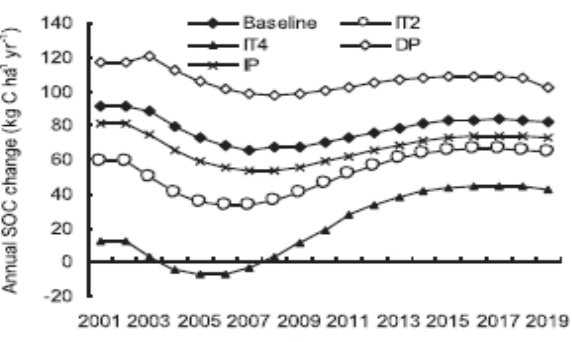

(d)

Fig.2 Schematic diagram showing different pathways of nitrogen in crop residue amended soils

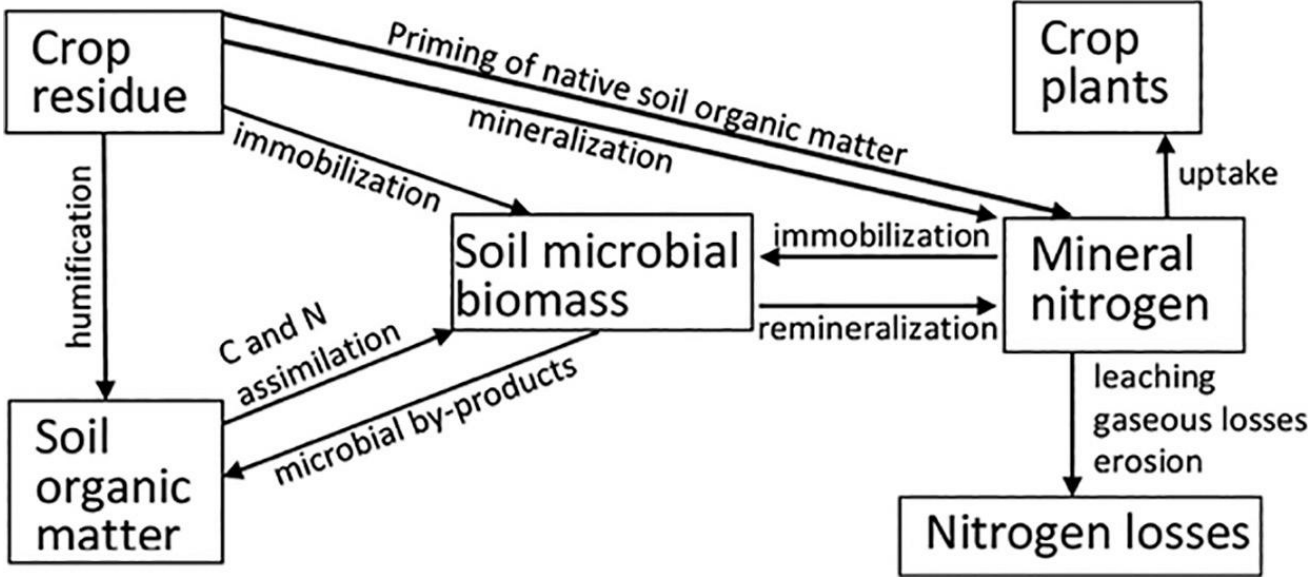

Fig.3a Effect of organic and inorganic fertilizers on bulk density after rice and wheat crop

Fig.3b Effect of organic and inorganic fertilizers on water holding capacity after rice and wheat crop

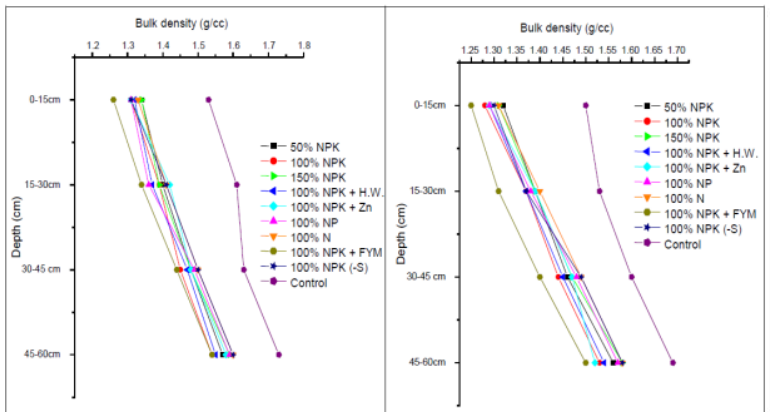

(a)

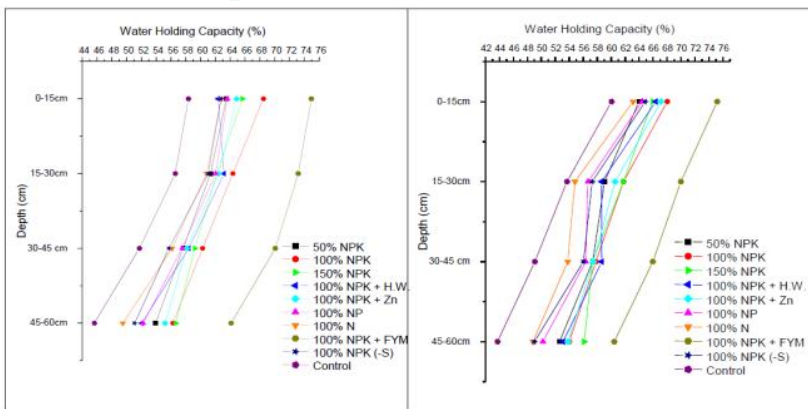

(b) 
Fig.4a Effect of organic and inorganic fertilizers on mean weight diameter after rice and wheat crop; Fig.4b Effect of compost applications on the distribution of waterstable aggregates

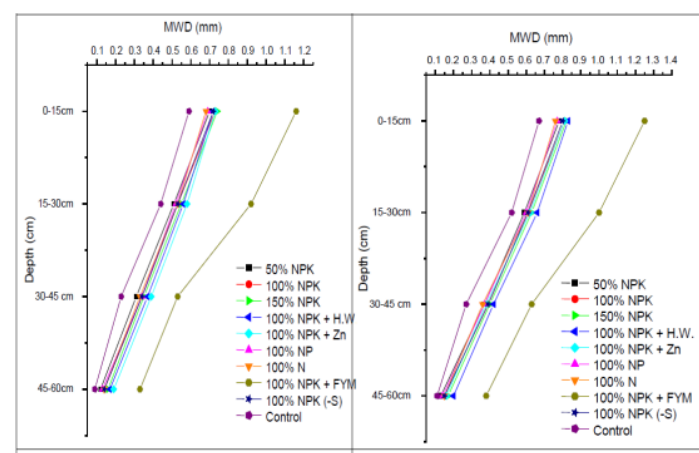

(a)

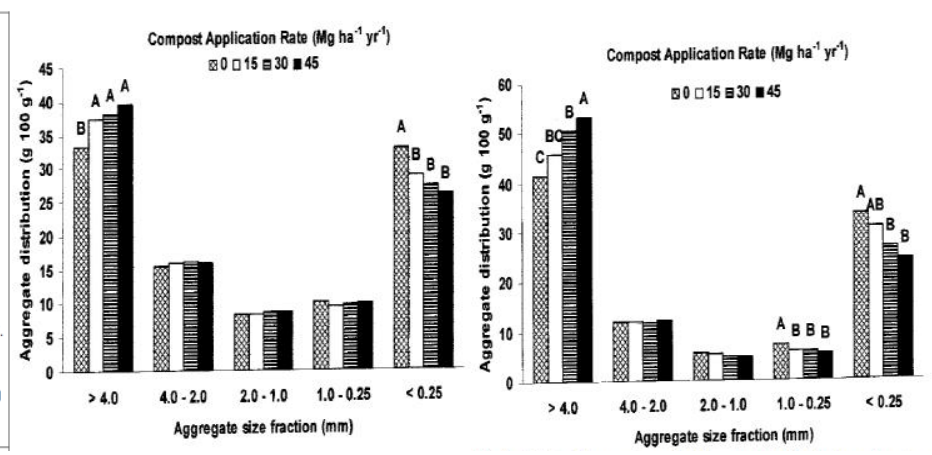

(b)

Fig.5a Soil aggregate distribution in the $0-5 \mathrm{~cm}(\mathrm{~A}), 5-10 \mathrm{~cm}$ (B) and $10-20 \mathrm{~cm}$ (C) depths under different tillage systems

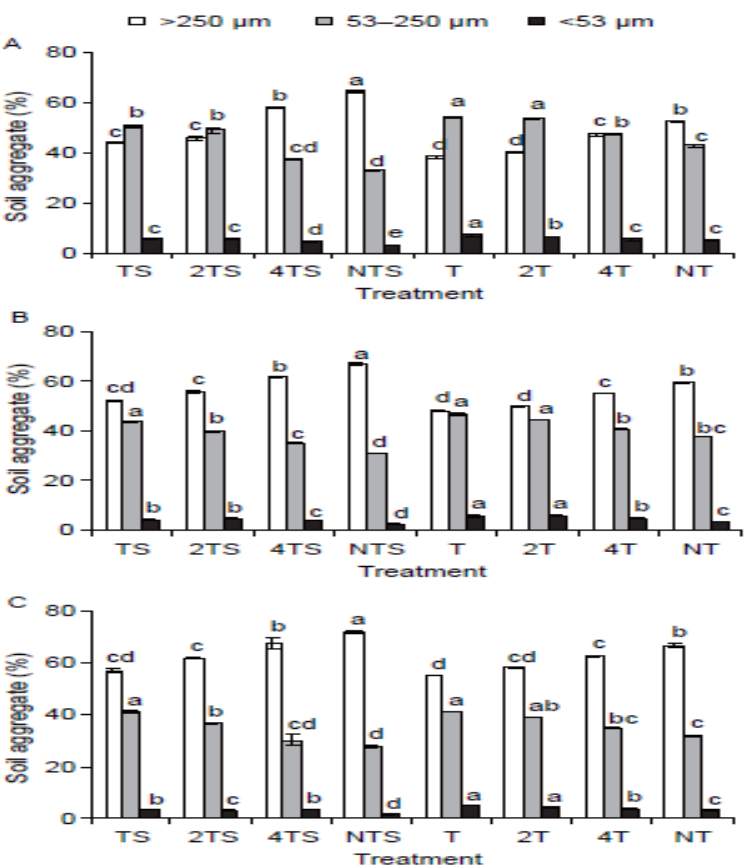

(a)

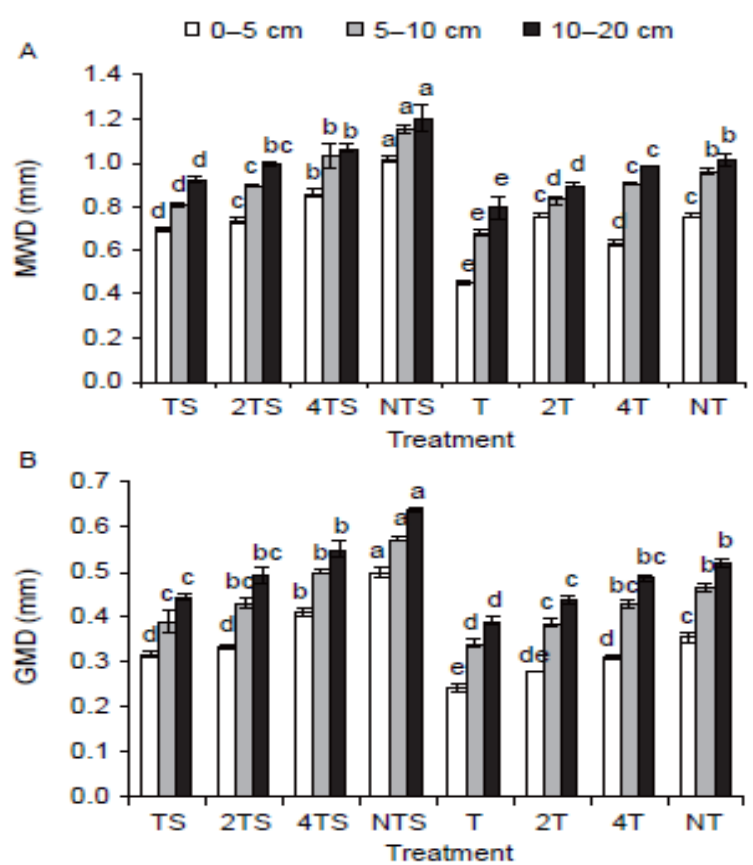

(b) 
Table.4 Effect of rice straw incorporation on structural indices and distribution of particle size (0-0.15 $\mathrm{m}$ depth) in rice-wheat system after 21 years

\begin{tabular}{|l|l|l|l|l|l|l|l|}
\hline \multicolumn{9}{|c}{} & \multicolumn{3}{l|}{ Mechanical Analysis } \\
\hline Treatment & WSMA(\%) & AR & AS(\%) & MWD(mm) & Sand(\%) & Silt(\%) & Clay(\%) \\
\hline Native & $76.8^{\mathrm{a}}$ & $3.31^{\mathrm{a}}$ & $76.75^{\mathrm{a}}$ & $1.57^{\mathrm{a}}$ & 12.1 & 32.0 & 55.9 \\
\hline Control & $41.0^{\mathrm{c}}$ & $0.60^{\mathrm{d}}$ & $39.30^{\mathrm{c}}$ & $0.60^{\mathrm{d}}$ & 11.1 & 32.0 & 56.9 \\
\hline NPK & $63.2^{\mathrm{b}}$ & $1.72^{\mathrm{c}}$ & $63.20^{\mathrm{b}}$ & $0.61^{\mathrm{d}}$ & 11.1 & 30.0 & 58.9 \\
\hline NPK+FYM & $75.6^{\mathrm{a}}$ & $3.10^{\mathrm{a}}$ & $75.05^{\mathrm{a}}$ & $1.11^{\mathrm{b}}$ & 13.1 & 30.0 & 56.9 \\
\hline NPK+PS & $74.2^{\mathrm{a}}$ & $2.88^{\mathrm{b}}$ & $73.24^{\mathrm{a}}$ & $0.89^{\mathrm{c}}$ & 17.1 & 34.0 & 48.9 \\
\hline NPK+GM & $72.4^{\mathrm{a}}$ & $2.62^{\mathrm{b}}$ & $71.80^{\mathrm{a}}$ & $0.88^{\mathrm{c}}$ & 11.1 & 38.0 & 50.9 \\
\hline
\end{tabular}

WSMA, water soluble macro-aggregate; AR, aggregate ratio of macro and micro; MWD, mean- weight diameter. Note: Superscript of a, b, c and d are the degrees of significance in DMR Test

Fig.6a Soil bulk density at various depths of texturally different soils under conventional (CT) and zero (ZT) tillage; Fig.6b Saturated hydraulic conductivity, field water capacity and aeration porosity of various depths of texturally different soils under conventional (CT) and zero (ZT) tillage.
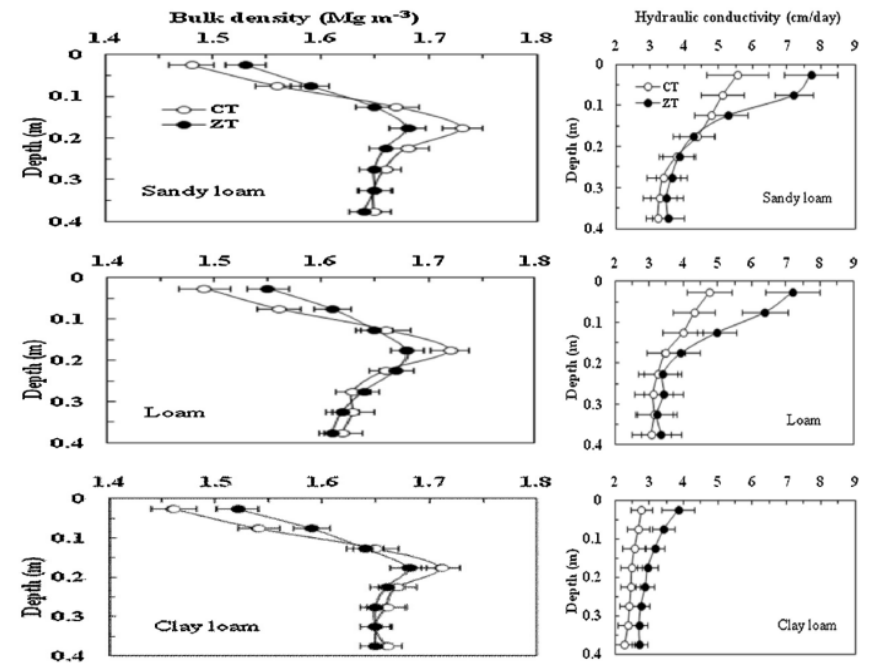

(a)
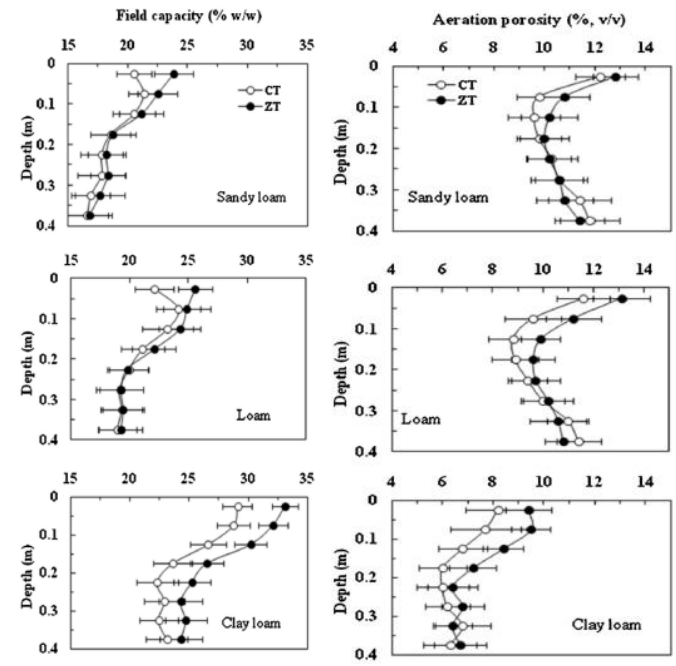

(b)
Zheng et al., (2018) reported that stability of water-stable soil aggregates, as measured by $G M D, M W D$, and $E_{L T}$ varied with soil layers under different treatments. For the ST and NT treatments, GMD decreased with an increase in depth, but for the MP and CT treatments $G M D$ increased initially with a subsequent decrease with depth. At the 0-10 and $10-20 \mathrm{~cm}$ depths, ST exhibited significantly higher values of GMD than for the other treatments, and at each depth from 20-50cm, ST was significantly higher than at least one other treatment. $M W D$ was higher at $0-20 \mathrm{~cm}$ than at the $20-60 \mathrm{~cm}$ depths for the ST and NT treatments but was opposite for the MP and CT treatments. In the top $20 \mathrm{~cm}$ of soil, the ST and NT treatments outperformed the MP and CT treatments. The mean for the overall $0-60 \mathrm{~cm}$ depth showed an intertreatment comparison of $\mathrm{ST}>\mathrm{NT}>\mathrm{MP}>\mathrm{CT}$, with significant differences between ST/NT and CT. However, $E_{L T}$ under different tillage 
treatments varied with soil depth, increasing with depth for the ST and NT treatments, but initially increasing and then decreasing for the MP and CT treatments. $E_{L T}$ was significantly higher for the CT treatment at depths of $0-10$, $20-30,30-40$, and $50-60 \mathrm{~cm}$, and was on average higher in the $\mathrm{CT}$ and MP treatments.

In conclusion, conventional system of tillage in rice-wheat cropping system was found to develop a compaction pan beneath the usually tilled layer of $0.15 \mathrm{~m}$ in different textured soils under rice cultivation in while the ZT system used in wheat helped in reducing this sub-soil compaction. Soil physical properties were improved as a consequence of decreased disturbance and crop residue cover on the surface in ZT system. ZT practice resulted in increased organic carbon, field water capacity and aeration status in soils. Lower subsoil bulk density and reduced water dispersible silt + clay contents resulted in increased saturated hydraulic conductivity, and infiltration rate favorable for better soil physical properties. The application of optimal dose of NPK $(100 \%)$ along with FYM in rice-wheat cropping system improved the soil physical properties i.e., improved aggregate stability, decrease in bulk density, increased saturated hydraulic conductivity and improved soil water-holding capacity of soil in comparison to application of NPK fertilizers alone. The physical properties play a vital role for the nutrient turnover and long-term productivity of the soil which are enhanced by balanced application of nutrients and manure. Continuous cropping of rice-wheat with imbalanced nutrient management declined the physical properties of soil. SOC concentrations and storage were highest in surface soil and depth interval down to $60 \mathrm{~cm}$ under $\mathrm{NP}+\mathrm{FYM}$ and $\mathrm{NP}+\mathrm{S}$, below which concentrations did not change with depth. At the same time, on average the estimate of soil C storage to $60 \mathrm{~cm}$ depth was higher than that for soil $\mathrm{C}$ accumulated to $20 \mathrm{~cm}$ depth and to
$40 \mathrm{~cm}$ depth, respectively. The estimate of soil $\mathrm{C}$ accumulation to $60 \mathrm{~cm}$ depth was more effective than that for soil $\mathrm{C}$ accumulated to $20 \mathrm{~cm}$ depth and to $40 \mathrm{~cm}$ depth. NP+FYM were the most efficient management system for sequestering SOC. A large amount of $\mathrm{C}$ was also sequestered in soil under $\mathrm{NP}+\mathrm{S}$ treatment. Organic and synthetic fertilizers also had a positive effect on the redistribution of SOC among the particle-size fractions, with obvious depletion of SOC in fine particles and pronounced enrichment in macro-aggregates. However, the enrichment factors of SOC in macro-aggregates of all treatments were $>1$ and that of microaggregates were $<1$ in both soil layers, indicating $\mathrm{C}$ sequestration in macroaggregates and $\mathrm{C}$ depletion from microaggregates. Hence, the enrichment factor of SOC is a better indicator than the labile: recalcitrant $\mathrm{C}$ to assess $\mathrm{C}$ sequestration within aggregates. Thus, returning crop residue to the soil or adding farmyard manure on the soil surface is crucial to improving the SOC level. The location of $\mathrm{C}$ stabilization in aggregate size fraction from the added organics might be dependent on the amount and the nature of bio-chemicals present in organics and their array with mineral particles and will help to enhance the capacity of carbon sequestration.

\section{References}

Abid, M., and Lal, R. 2009. Tillage and drainage impact on soil quality. II. Tensile strength of aggregates, moisture retention and water infiltration. Soil Tillage Res., 103: 364-372.

Anantha, K.C., Majumder, S.P., Dhaneshwar Padhan, Badole, S., et al., 2018. Carbon dynamics, potential and cost of carbon sequestration in double rice cropping system in semi arid southern India. J. Soil Sci. Plant Nutr. 18(2): http://dx.doi.org/10.4067/S0718- 
95162018005001302

Angers, D.A., and Eriksen-Hamel, N.S. 2008. Full inversion tillage and organic $\mathrm{C}$ distribution in soil profiles: A metaanalysis. Soil Sci Soc Am J., 72:13701374

Aulakh, M.S., Garg, A. K., and Kumar, S. 2013. Impact of Integrated Nutrient, Crop Residue and Tillage Management on Soil Aggregates and Organic Matter Fractions in Semiarid Subtropical Soil under Soybean-Wheat Rotation. Am. J Plant Sci., 4: 2148-2164.

Awanish, K. 2016. Impact of conservation agriculture on nutrient dynamics in dominant cropping systems in a black soil of central India. Ph.D. Thesis, Indira Gandhi Krishi Vishwavidyalaya Raipur, Chhattisgarh.

Bhattacharyya, R., Chandra, S., Singh, R.D., Kundu, S., Srivastva, A.K., Gupta, H.S. 2008. Long-term farmyard manure application effects on properties of a silty clay loam soil under irrigated wheat-soybean rotation. Soil Tillage Res., 94: 386- 396.

Cai, L.Q., Qi, P., Zhang, R.Z., and Li, A. Z. 2009. Effects of different conservation tillage measures on soil organic carbon pool in two sequence rotation systems of spring wheat and peas. Chinese $\mathrm{J}$ Eco-Agri., 17(1):1-6.

Celik, I., Ortas, I., and Kilic, S. 2004. Effects of compost, mycorrhiza, manure and fertilizer on some physical properties of a Chromoxerert soil. Soil Tillage Res. 78: 59-67.

Desjardins, R.L., Kulshreshtha, S.N., Junkins, B., Smith, W., Grant, B., and Boehm, M. 2001. Canadian greenhouse gas mitigation options in agriculture. Nutr. Cycl. Agroecosys., 60: 317-326.

Fujisaki, K., T. Chevallier, L. Chapuis-Lardy, A. Albrecht, T. Razafimbelo, D. Masse, Y. B. Ndour, and J.-L. Chotte. 2018. Soil Carbon Stock Changes in Tropical
Croplands Are Mainly Driven by Carbon Inputs: A Synthesis. Agri Ecosyst Environ., 259: 147-158.

Ghosh, A., Bhattacharyya, R., Meena, M.C., Dwivedi, B.S., Geeta Singh, Agnihotri, R. et al., 2018. Long-term fertilization effects on soil organic carbon sequestration in an Inceptisol. Soil Tillage Res. 177:134-144.

Gollany, H.T., Allmaras, R.R., Copeland, S.M., Albrecht, S.L., and Douglas Jr, C.L. 2006. Tillage and nitrogen fertilizer influence on $\mathrm{C}$ and soluble silica relations in a Pacific Northwest Mollisol. Soil Sci Soc Am J., 69:11021109.

Guo, L-J., Lin, S., Liu, T-Q., Cao, C-G., and Li, C-F. 2016. Effects of Conservation Tillage on Topsoil Microbial Metabolic Characteristics and Organic Carbon within Aggregates under a Rice (Oryza sativa L.) -Wheat (Triticum aestivum L.) Cropping System in Central China. PLoS ONE 11(1): e0146145.

Gupta Choudhury, Shreyasi., Sonal Srivastava, Ranbir Singh, Chaudhari, S.K., Sharma, D.K., Singh, S.K. and Dipak Sarkar. 2014. Tillage and residue management effects on soil aggregation, organic carbon dynamics and yield attribute in rice-wheat cropping system under reclaimed sodic soil. Soil Tillage Res, 136:76-83.

Kakraliya, S.K., Jat, R.D., Kumar, S., Choudhary, K.K., Prakash, J., and Singh, L.K. 2017. Integrated nutrient management for improving, fertilizer use efficiency, soil biodiversity and productivity of wheat in irrigated rice wheat cropping system in IndoGangatic plains of India. Int. J. Curr. Microbiol. App. Sci. 6(3): 152-63.

Khurshid, K.M., Iqbal, M., Arif, S., and Nawaz, A. 2006. Effect of tillage and mulch on soil physical properties and 
growth of maize. Int. J Agri Bio. 8:593596.

Kopittke, P. M., M. C. Hernandez-Soriano, R. C. Dalal, et al., 2018. Nitrogen-Rich Microbial Products Provide New Organo-Mineral Associations for the Stabilization of Soil Organic Matter. Glob Change Biol., 24(4): 1762-1770.

Lal, R. 2004a. Soil carbon sequestration to mitigate climate change. Geoderma 123: $1-22$.

Lal, R. 2004b. Soil carbon sequestration impacts on global climate change and food security. Science 304: 1623-1627.

Lal,R., and Stewart, B.A. Eds., Principles of Sustainable Soil Management in Agro ecosystems, 20, CRC Press 2013,

Lehmann, J., and M. Kleber. 2015. The Contentious Nature of Soil Organic Matter. Nature 528 (7580): 60-68.

Lenka, S., P. Trivedi, B. Singh, B. P. Singh, E. Pendall, A. Bass, and N. K. Lenka. 2019. Effect of Crop Residue Addition on Soil Organic Carbon Priming as Influenced by Temperature and Soil Properties. Geoderma 347: 70-79.

Liu, E., Yan, C., Mei, X., Zhang, Y., and Fan, T. 2013. Long-Term Effect of Manure and Fertilizer on Soil Organic Carbon Pools in Dryland Farming in Northwest China. PLoS One 8(2): e56536.

Naresh, R.K., Gupta, Raj K., Gajendra Pal, Dhaliwal, S.S, Kumar, D., Kumar V., Arya, V. K., et al., 2015. Tillage crop establishment strategies and soil fertility management: resource use efficiencies and soil carbon sequestration in a ricewheat cropping system. Eco. Env. \& Cons. 21:127-134.

Naresh, R.K., Gupta, Raj K., Singh, S.P. Dhaliwal, S.S. et al., 2016. Tillage, irrigation levels and rice straw mulches effects on wheat productivity, soil aggregates and soil organic carbon dynamics after rice in sandy loam soils of subtropical climatic conditions. J
Pure Appl Micro-bio., 10(2): 10601080.

Pan, G.X., and Zhao, Q.G. 2005. Study on evolution of organic carbon stock in agricultural soils of China: facing the challenge of global change and food security. Adv Earth Sci., 20(4):327337.

Pant, P.K., and Shri Ram. 2018. Long-Term Manuring and Fertilization Effects on Soil Physical Properties after Forty Two Cycles under Rice-Wheat System in North Indian Mollisols. Int. J. Curr. Microbiol. App. Sci., 7(7): 232-240.

Sarker, J. R., B. P., Singh, A. L., Cowie, Y., Fang, D., Collins, W. J., Dougherty, and Singh, B.K. 2018b. Carbon and Nutrient Mineralization Dynamics in AggregateSize Classes from Different Tillage Systems after Input of Canola and Wheat Residues.Soil BiolBiochem., 116: 22-38.

Singh, A., Phogat, V.K., Dhaiya, R., and Batra, S.D. 2014. Impact of long-term zero till wheat on soil physical properties and wheat productivity under rice-wheat cropping system. Soil Tillage Res., 140:98-105.

Singh, G., Jalota, S.K., and Singh, Y. 2007. Manuring and residue management effects on physical properties of a soil under the rice-wheat system in Punjab, India. Soil Tillage Res. 94: 229-238.

Smit, B., and Skinner, M.W. 2002. Adaptation options in agriculture to climate change: a typology. Mitig. Adaptat. Strat. Gl. 7: 85-114.

Sun, H., Larney, F.J., and Bullock, M.S. 1995. Soil amendments and waterstable aggregation of a desurfaced Dark Brown Chernozem. Can. J. Soil Sci. 75:319-325.

West, T.O., and Post, W.M. 2002. Soil organic carbon sequestration rates by tillage and crop rotation. Soil Sci. Soc. Am. J., 66: 1930-1946. 
Whalen, J.K., Hu, Q., and Liu, A. 2003. Compost Applications Increase WaterStable Aggregates in Conventional and No-Tillage Systems. Soil Sci. Soc. Am. J. 67:1842-1847.

Xin, S., Anning, Z., Jiabao, Z., Wen-liang, Y., Xiu-li, X., and Xian-feng, Z. 2015. Changes in soil organic carbon and aggregate stability after conversion to conservation tillage for seven years in the Huang-Huai-Hai Plain of China. J Int Agri., 14(6): 1202-1211.

Zhang, L., Zhuang, Q., He, Y., Liu, Y., Yu, D., Zhao, Q., Shi, X., Xing, S., and Wang, G. 2016. Toward optimal soil organic carbon sequestration with effects of agricultural management practices and climate change in TaiLake paddy soils of China. Geoderma 275:28-39.

Zheng, H., Liu, W., Zheng, J., Luo, Y., Li, R., Wang, H., et al., 2018. Effect of longterm tillage on soil aggregates and aggregate-associated carbon in black soil of Northeast China. PLoS ONE 13 (6): $\mathrm{e} 0199523$

Zheng, Z.C., Liu, M.Y., and Li, T.X. 2013.Distribution characteristics of organic carbon fractions in soil aggregates under tea plantation of different ages. Scientia Agricultura Sinica 46(9):1827-1836.

\section{How to cite this article:}

Omkar Singh, R.K. Naresh, Vivek, Shivangi, P.K. Singh, M. Sharath Chandra and Abhineet. 2020. Toward Optimal Soil Organic Carbon Sequestration and Soil Physical Properties with Effects of Conservation tillage, Organic and Synthetic Fertilizers under RWCS in an Inceptisol: A Review. Int.J.Curr.Microbiol.App.Sci. 9(08): 526-542. doi: https://doi.org/10.20546/ijcmas.2020.908.060 